\title{
Liberation as a Correlate of Religiosity: A Christian-Muslim Perspective on Fundamental Trust
}

\author{
Jakub Urbaniak \\ Department of Church History and Church Polity, \\ Faculty of Theology, University of Pretoria, South Africa
}

\begin{abstract}
This article explores the dialectical relationship between liberating trust in reality and religious faith in God, interpreted from a Christian-Muslim perspective. An underlying conviction is that liberation constitutes a necessary mutual correlate of a "true" religiosity, i.e., liberation is to be conceived as both prerequisite for and realization of a genuine religiosity, and vice versa. As opposed to a "true" religiosity, born from liberating trust and finding its fulfilment in prophetic action aimed at liberation of human realities, religious belief and practice that stem from fundamental mistrust are likely to deteriorate into either religious fundamentalism or indifferentism. The article focuses on fundamental trust in reality as capable of evoking the liberating and uniting force of religious theory and praxis. It aims to render explicit the religious and ecumenical potential (hitherto not fully realized) of the theological-ethical considerations of Hans Küng, in particular within a Christian-Muslim framework. The first part of the article, more conceptual in character, examines Küng's views on fundamental (mis)trust and its religious implications. The second part seeks to identify theological insights that shed light on the specifically Christian and specifically Muslim interpretations of liberating trust. My hope is that this study may contribute to a truly global ecumenism whose objective is to render religion an instrument of liberation, not oppression.
\end{abstract}


Keywords: fundamental trust; global ecumenism; Hans Küng; pluralism;

Christianity; Islam; Christian-Muslim dialogue; interfaith; interreligious; charis; pistis; caritas; ìmān; islām; salām

To be as free as it is humanly possible to be free can only come about when full submission and surrender to Reality is achieved ... Hence freedom from the unreal comes down to the same as freedom for the Real. There can be no contradiction. Both are tawhīd. (Murata 2006, 115)

In both modern and postmodern contexts, the paradox of religion and liberation has been considered mainly in terms of liberation (moral, cultural, scientific, etc.) from a religious (confining and divisive) vision of reality which still tends to be juxtaposed with its secular (autonomous and emancipative) "counteroffer." In recent decades, this one-sided trend has been challenged; it has emerged more clearly than before that religions, which have so often contributed to human oppression, have rich resources that can be used to restore and perfect human freedom. This issue has been reflected upon not only by liberation theologians, of both Christian (e.g., Gustavo Gutiérrez) and Islamic (e.g., Farid Esack) provenance, but also within the ecumenically oriented theology of religions that targets what Hans Küng calls global responsibility based on global ethics. While keeping these references in mind, this article focuses on the more nuanced and less obvious aspect of the interrelationship between liberation and religion, namely fundamental trust in the world and one's own self.

The article seeks to explore the mutual correlation between trust in reality and religious faith in God, interpreted from a Christian-Muslim perspective, and argues that such 
trust is capable of evoking the liberating and uniting force of both Christian and Muslim theory and praxis. An underlying conviction is that, as religious believers, we are freed to trust and, at the same time, by trusting we realize our ultimate freedom. Such liberation, which both emerges from trust and allows it, constitutes a necessary and mutual correlate of "true" religiosity. To render these claims more theologically verifiable and contextually rooted, they will be tested in light of the selected insights on faith conceived of as trust that can be found in both Christian and Muslim traditions. A further aim will be to render explicit the religious and ecumenical potential (hitherto not fully realized) of the theological-ethical thinking of Hans Küng, who is our guide on that journey.

The first part of the paper, more conceptual in character, examines Küng's views on fundamental (mis)trust and its religious implications. The second part - using analogical imagination (David Tracy) - seeks to identify theological insights that shed light on the specifically Christian and specifically Muslim interpretations of liberating trust. The hope is that such a study can contribute to ongoing discussion regarding the shape of a truly global ecumenism whose objective is to render religion an instrument of liberation, not oppression.

\section{Fundamental (mis)trust and its religious implications}

First, we must gain a proper understanding of what Küng means by fundamental (mis)trust and how it correlates to religious faith. Against this background, I shall argue that only religious belief and practice that are born from liberating trust can find their fulfilment in prophetic action aimed at the radical liberation of human realities. Religiosity that stems from fundamental mistrust, on the other hand, is likely to deteriorate into either religious fundamentalism or indifference - the first of which confines the person to what is her own, while the second condemns her to some sort of spiritual anonymity. 


\section{Fundamental decision in regard to uncertain reality}

I don't know Who - or what - put the question, I don't know when it was put. I don't even remember answering. But at some moment I did answer Yes to Someone - or Something - and from that hour I was certain that existence is meaningful and that, therefore, my life, in self-surrender, had a goal ... After that, the word "courage" lost its meaning, since nothing could be taken from me. (Hammarskjöld 1964, 169)

These are the words of Dag Hammarskjöld, Secretary-General of the United Nations, written at Pentecost 1961, four months before his death on the Congo border, when carrying out a peace mission. His personal witness reflects beautifully what Küng means by fundamental trust in reality as a whole.

As human beings, we are (existentially) immersed in and(cognitively) presented with an uncertain reality to which we can, in principle, adopt either a positive or a negative attitude. This reality is identical with all that constitutes the world in space and time, including other human beings and, in a special way, myself: "I" who as subject can become object to myself. Because the world is broken and the human person is all too human, we find ourselves threatened by the nothingness, transitoriness and finiteness of all that is human and earthly. At the same time, we are somewhat inclined to say 'Yes' to this uncertain reality, which, when accepted trustfully, reveals to us its identity, meaning and value. Since reality is not self-evident, i.e., it does not extort a positive or a negative basic attitude, an essentially free and always risky decision vis-à-vis everything that exists must be made, in which a person risks herself without any security or guarantee. Thus is the basically existentialist account of what Kierkegaard named the great "Either/Or," what Ignatius Loyola in the Exercises called "electio," and what Sartre meant by "choix original” (Küng 1980, 427-477). 
An evident tension can be seen between the purely subjective (the early Kierkegaard) and the specifically Christian (the late Kierkegaard) meaning of fundamental decision. On the one hand, this choice appears to be purely a priori, free and spontaneous. On the other, as humans we face various limit-situations that seem to disclose to us our basic existential trust or mistrust in life's very meaningfulness. Such limit-situations may basically take the form of either the "boundary-situations" of guilt, anxiety, suffering and the recognition of death as one's own destiny, or "ecstatic experiences" of intense joy, love, gratitude, etc. (Jaspers 1967). Christian theology interprets the former as the existential manifestations of the universal need of redemption and the latter as encounters with the final dimension of human existence, as glimpses of grace (Tracy 1975, 105-106). Analogically, Muslims, who believe that Allah establishes all the preconditions for what human beings do with their freedom (Engineer 1990, 14), understand limit-situations in terms of the good (khayr) and evil (sharr) that are measured out by God (Murata 2006, 107-108). Both dimensions - autonomous and transcendental - must be preserved in a dialectical tension: "fundamental option" consists in a free, but not arbitrary, responsibly effected and potentially justifiable, but not necessarily reflected upon or provable, basic reaction to reality as a whole, on which all subsequent individual options are based.

\section{Belief in God as an ultimately justified fundamental trust}

The final horizon of our human situation is neither one of our own making nor one under our control - this much is clear to all existentialists. However, this elusive dimension cannot become the actual ground for personal trust unless, to use Buber's famous distinction, it is named and addressed not as "it" but as "thou" (1937). As Luther rightly pointed out, that to which our heart clings and entrusts itself (tui fiduciam et cor fixum habueris) is really our God $(1959,365)$. To reverse his thought, we might say that, unless our heart clings and 
entrusts itself to the primary ground, deepest support and ultimate goal of reality, we are not capable of encountering there a living God. Only when referred to as "thou," does the final dimension, the "Ground of Being" (Tillich 1951, 64), reveal itself as a person-like yet transpersonal power of unbounded love that both accepts trust and bestows it. When a person commits herself to reality, that reality itself lays open to her its ultimate horizon - what believers call "God." On the other hand, unless a person commits herself trustingly to God (as the primal source, meaning, and value of all that is), her trust in reality cannot be ultimately justified. Hence the dialectics of trust and faith: God alone can provide the ultimate response to the radical uncertainty of reality, but God's existence cannot be assumed otherwise than in a trust rooted in reality itself. Put differently, religious faith in God implies an ultimately justified fundamental trust in uncertain reality, but it also suggests the condition of its possibility (Küng 1980, 572).

The affirmation of God rests, in the last resort, on a decision that is organically connected with the fundamental option for reality as a whole. Only belief in God rooted in fundamental trust can suggest the condition of the possibility of uncertain reality. What is more, nothing except trust in God can evoke from universal trust its deeply liberating power. A reasonable trust in reality, which lies behind - and alone makes possible - any individual trust at all, appears thereby as the central content of religion: both as fundamental trust in regard to uncertain reality and as a personal trust in God understood as the all-embracing, allpenetrating last and first Reality (Küng 2001, 45).

\section{Liberating trust as a correlate of a "true religiosity"}

Liberation from suspicion and mistrust in regard to reality constitutes a necessary correlate of a "true" religiosity. Such is the central thesis that underlies my analysis. Mutual correlation between liberation and religiosity is to be understood in the sense ascribed to this notion by 
Tracy, i.e., liberation as both prerequisite for and realization of a genuine religiosity, and vice versa. Liberating trust should be seen not only as an antidote to a perverted religiosity but also as the sine qua non condition of an authentic religious faith. It is to these varying religious implications of fundamental (mis)trust that I now turn.

Erikson (1980, 64-65) describes three distinct possible relationships between trust and faith: (1) a fundamental trust that comes from religious faith; (2) a fundamental trust without religious faith; and (3) a religious faith without fundamental trust. There is no reason why we should not reverse the first proposition: (4) a religious faith that comes from fundamental trust. Possibilities (1) and (4) constitute a positive expression of the mutual correlation between fundamental trust and religious faith, whereas possibilities (2) and (3) witness to the shortcomings of both trust, which remains closed to a "transcendence with a name" and thereby essentially deficient, and faith which, built upon fundamental mistrust in reality, likely lapses into some sort of religious absolutism or relativism. While the first perverts and trivializes the question of truth, the second no longer even dares to ask it (Küng et al. 1986, xix).

According to Küng $(2001,54)$, the pivotal role of religion consists in communicating a "specific depth-dimension and all-embracing horizon of meaning, even in the face of suffering, injustice, guilt, and meaninglessness, and also a last meaning of life even in the face of death." No religion can perform this function properly unless it is being constantly freed from a hermeneutics of suspicion, and so challenged and empowered to transcend such hermeneutics in a forward movement toward the trust of a "second naïveté" that results in a mature hermeneutics of trust. That also means that the universal human desire for liberation and authentic existence cannot be fulfilled by a religion that is not rooted in fundamental trust in reality. To fully enter this particular social realization of a relationship to an absolute ground of meaning, a believer must first be liberated from basic mistrust; otherwise, reality cannot "refer" him or her to its primal ground, support and goal. The uncertain reality that we 
allow to confine us to our fearful conjectures, rather than revealing its final horizon, shows us only that which is chaotic, absurd and illusive. To reality thus perceived we will surely say "No," and even if we say "Yes," we cannot ultimately justify why we do so. Neither of these two attitudes enables one to become a truly religious person. However, Küng (1980, 445446) holds that since reality itself - its identity, orderliness, meaningfulness, and value - is thrust on us, by our very nature we are inclined not to the "No" but to the "Yes". If that is the case, then it can be maintained that the human person is, in a sense, inherently religious, which is to say, endowed with predisposition to a genuine religiosity grounded in liberating trust.

And yet even an individual or group whose religiosity is built upon confining mistrust may continue to function religiously in a social framework, preserving the appearances of "religiosity" in the proper sense of the term. In such a context, religious perversions present in all spiritual traditions without exception can and should be distinguished from a "principled religiosity," a "genuine religiosity," which - far from being an elusive ideal - is also instantiated in all the world religions without exception. ${ }^{1}$

The criterion Küng uses to distinguish a "true" religiosity from a "false" one is that of its theological foundation and socio-religious implications. Based on such a criterion, he offers the following three characteristics of a "true religiosity" (1996, 283): (1) Religiosity with a foundation, but without fundamentalism; (2) Religiosity with certainty of truth, but without fanaticism; (3) Religiosity with religious identity, but without exclusivity. A closer look at trends prevailing in the present theology of religions (at least, that of Christian origin) makes one realize that what poses perhaps the most urgent challenge today is the problem of "religiosity without religious identity.” Hence my fourth proposal aimed at complementing Küng's perspective: (4) Religiosity with unity-in-difference, but without univocity. 
In the second part of the article, these four principles will be considered from the Christian-Muslim point of view and the somewhat abstract concepts presented so far will thereby be endued with theological flesh.

\section{Freed by trust: liberation from a Christian-Muslim perspective}

Both Christianity and Islam, as the religions of Semitic origin and prophetic character, traditionally begin from a contrast between God and human beings. Predominantly involved in religious confrontation and often fixated on dominating the other, these "predatory religions" - to use Scott Alexander's phrase (2013) - tend to "set their adherents at odds, not only with one another, but with people of a variety of different faiths, or no particular faith at all.”. That being the case, Christianity and Islam are particularly susceptible to religious fundamentalism, fanaticism and exclusivity (Küng 2001, 128). In our day, however, both traditions - though Christianity to a greater extent - are also exposed to the pitfalls of (apparently the most innocent) univocity. All these perversions of a "wholesome religiosity" effectively destroy a dimension to our lives that religion is meant to promise, restore and liberate (Tracy 1975,135$).{ }^{2}$ One can hardly deny the fact that the most fanatical and cruel political struggles throughout history were (and still are) coloured, inspired or legitimized by religion (Küng 1988, 227). To become the agents of reconciliation and peace, both Christians and Muslims must first recognize that the boundary between liberation and oppression does not run simply between different religious traditions but also at least in part within each of them.

\section{Boundaries between liberation and oppression pass through each religion}

The degree to which a religion is liberating or oppressive can be measured with the help of the three criteria proposed by Küng: the general ethical criterion, the general religious criterion, and the specifically Christian/Muslim criterion. 


\section{(1) The general ethical criterion.}

According to the first criterion, a religion is true and good if and insofar as it is human, does not suppress and destroy humanity, but protects and furthers it (Küng 2001, 97-98). Insofar as it feeds on mistrust and suspicion, a religion hinders women and men in their identity, sense of meaning, and sense of dignity, and thus condemns them to some sort of enslavement, instead of setting them free and enabling them to fully actualize their human potential. A meaningful and fruitful existence cannot be contributed to by religious doctrines of faith and morals, rites and institutions that disseminate inhumanity and oppression stemming from mistrust in universally human values (91).

\section{(2) The general religious criterion.}

According to the second criterion, a religion is true and good if and insofar as it remains true to its own origin, to its authentic "nature", its normative scripture or figure, and constantly refers to it. As a consequence, also "a truly liberative theology must evolve out of or at least be connected to what Cornel West calls 'the core message' of the tradition" (Omar 2008, 97). Unless it is to remain abstract, this principle cannot be seen in isolation from the third of Küng's criteria, namely a benchmark for a particular religious tradition. According to (3a) the specifically Christian criterion, a religion is true and good if and insofar as it shows the spirit of Jesus Christ in its theory and praxis (Küng 2001, 98). Analogically, according to (3b) the specifically Muslim criterion, a religion should be considered true and good if and insofar as it allows and encourages free, holistic and unconditional submission to the one and only God, as revealed in the Qur'an. ${ }^{3}$ What can be said about the demarcation line between the liberating and the oppressive in Christianity and Islam in the light of these two types of criteria? To answer that question adequately, we must first situate the notion of freedom within the framework of each tradition. 


\section{'Freedom' in Christian and Muslim teachings}

Both the Bible and the Qur'an overtly express trust in the human capacity for freedom. The Old Covenant is grounded in the free choice of the Israelites to live according to God's ways as a response to YHWH's free act of the selection of Israel (Deuteronomy 11.26; 30.15; Joshua 24.14-28). The New Testament likewise makes it a central aspect of human response to Jesus's proclamation of God's reign (Matthew 4.21-22; John 1.39; Galatians 5.1). Similarly, the divine revelation transmitted through the Prophet, presents Allah's absolute freedom not as a threat to the relative freedom of human beings, but - quite the opposite - as something that makes that freedom possible and trustworthy. The Muslim concept of freedom is rooted in the shahāda: 'There is no god but God' or - to use Murata's original translation $(2006,114)$ - "There is none free but God." Allah is free of any sort of outside constraint, "a sovereign doer of what He desires" (Q 11.107; 85.16, as quoted by Murata 2006, 114), an attribute that no creature shares with Him. Compared with God, all creatures dwell in utter slavery. And thus, in order for human beings to be free, they must partake of God's freedom $(2006,114)$.

Tracy $(1991,115)$ points out that however conflictual the Christian interpretations of freedom are (and they are), all of them assume three crucial facts: first, there is meaning to the word "freedom" insofar as that word refers to personal agency and responsibility; second, the ground of that freedom is Jesus Christ; and third, the centre of that freedom is the kind of agent disclosed by the narratives regarding the singular agency of this Jesus as the Christ. The Gospels present Jesus as the one who radically reinterprets the Old Testament understanding of the relationship between God and humanity; this reinterpretation is centred on the significance of human freedom. Jesus makes his followers realise that from now on true believers must worship God not on this or that mountain, but "in spirit and truth" (John 4.23). By challenging a too formal understanding of the commandments, he shifts the focus to the 
human "heart" (Matthew 15.19; 5.28). Nothing in the world can be considered "impure" in and by itself (Mark 7.18-23; Matthew 15.19-20). In the new order established by Jesus's Passover, the demarcation line between the things that belong to God and those that belong to the "ruler of this world" (John 12.31) runs not through time and space but through the conscience of every human person. Put negatively, only freedom through which a person identifies herself with her own sin can create in the human world a "place without God".

Since the time of Paul, the interpretation of true freedom can be summarised as the gift of freedom in Christ that both empowers and commands the believer to act responsibly before God and for others. Augustine placed this originally Pauline insight at the very core of Christian self-understanding and it has remained there, at least in the West, ever since. As noted by Tracy, while one aspect of that Augustinian heritage has been developed by the Thomist tradition in Catholic theology, ordinarily under the rubric of "grace and freedom,",5 the other has been most developed in the Protestant Reformation and in Catholic Jansenism. Furthermore, recent Christian prophetic reflection on freedom and agency owes much to the "deprivatising" of both Catholic and Protestant thought by political, liberation and feminist theologians (Tracy 1991, 110-111).

From an Islamic point of view, it is simply impossible to speak of God, humanity, society - or freedom, for that matter - without referring to the concept of tawhīd (God's "unity" or "oneness"). To assert this oneness is the supreme duty and passion of Islamic theology. From Allah's oneness the oneness of humankind is derived. This principle of unity reflects the complete - i.e., a meaningful and purposeful - harmony in which Islam situates God, humanity and nature (Shari'ati 1980, 86), whereby the ultimate goal of creation consists in the "submission of all things to the divine wisdom and command" (Murata 2006, 28). That is why any act of liberation has as its aim, first and foremost, to restore and safeguard the oneness of the human person and through that, ultimately, to observe and serve the oneness 
of God. The organic correlation between tawhì and freedom can be seen in the fact that the affirmation of Allah's oneness, manifested in belief and devotion, is in itself a powerful liberator of the inner conscience of the believer from dependence on anyone but God (Kamali 2002, 9). In the same vein, Bāqir Al-Ṣadr (2009) holds that, in Islam, human submission to God is the tool whereby the human person breaks all other norms of submission or slavery. Being muslims and 'abds by nature, humans can in fact never be free of God. And yet Allah wants them to recognize this and submit to Him voluntarily, for only through submitting themselves to God, that is to say, through freeing themselves up for God, can human beings free themselves from everything other than God.

Tawhìd involves simultaneous affirmation of tanzīh, God's otherness (incomparability with creatures), and of tashbīh, divine resemblance to creation. These two notions can be helpful in terms of understanding the paradox between free will and predestination which, according to Islam, are merely the two complementary expressions of the human situation, neither of which, on its own, expresses that situation fully. As Murata says $(2006,113-114)$ :

In respect of tanzīh, human reality is sheer unreality, since God is the only reality there is. Human beings have no knowledge, power, desire, or freedom, since these are divine attributes and belong exclusively to God. But in respect of tashbīh, human beings reflect these divine attributes. The attributes belong to God, but they are put into effect through human beings.

In brief, God's sovereignty in no sense deprives humans of their freedom; rather it lays down the limits, the framework for human actions and thus creates potentiality for accepting (Engineer 1990, 14). 
From this perspective, one might say that the Qur'an invites humankind to unite on two things, namely tawhīd and freedom: "We worship none but God and we associate no partner with Him, and none of us must be slaves or masters of one another other than God" (Q 3.64; as quoted by Kamali 2002, 10). As emphasized by Muhammad Iqbal, freedom is considered in Islam as a "Trust" that humans have accepted at their peril, thus becoming the trustees of Allah's sacred gift (Kamali 2002, 21; see also Q 33.72). Needless to say, as the vicegerents of their free personality, human beings bear responsibility for their actions, as their freedom is a prerequisite of accountability to God. However, to the extent that human beings were not free and guidance was not offered to them, they will not be held responsible for their actions (Murata 2006, 116). To sum up, Islam establishes a dialectical mutual relationship between freedom and surrender: its ultimate objective is to liberate people so that they can freely submit themselves to the one and only God. Thus, freedom lies ultimately in surrendering to the divine will (Kamali 2002, 9).

\section{Perversions of religion: freedom undermined}

The above understanding of freedom in the light of the Gospel and the Qur'an may be considered as something essential for Christianity and Islam. However, as Küng $(2007,20)$ reminds us, the essence of each faith shows itself only in what is changing. Thus, far from being a metaphysically immobile and remote concept, freedom in Christianity and Islam appears in a myriad of variable historical forms, often distant from what is constitutive of the founding religious message. The paradox consists in the fact that, in any religion, the abiding and the changing, essence and perversion, are so interwoven that human beings, who are themselves deeply ambivalent, can never clearly separate them (21). Many historical and contemporary examples (such as crusades and terrorism) make us painfully aware that, as a human phenomenon, religion is ambivalent and can be perverted even in the use of its most 
essential elements, such as the Bible or the Qur'an. Hence the need for an ongoing hermeneutic endeavour on the part of religious institutions and leaders, as well as each and every believer.

While avoiding an oversimplifying juxtaposition of faith and religion or charisma and institution, one should ask nonetheless whether Christianity and Islam trust in believers' capacity for using freedom, as Jesus and the Qur'an do. As the deepest characteristic of the human being, personal freedom always implies risk and taking responsibility for oneself, not merely following authority (von Sinner 2005, 323). In this sense, both Christian churches (especially their hierarchy) and Muslim communities (especially their leaders, who in some cases combine religious and political power) are "constantly being challenged by God who calls us to an ethics of mutual trust" $(334){ }^{6}$

A major factor in all common perversions of religion, namely fundamentalism, fanaticism, and exclusivity, whether of Christian or Muslim provenance, is deep mistrust of reality. Such suspicion stems from the essential misunderstanding (or ignorance) of the fact that, for Christians, the entire creation has been redeemed and reconciled to God through Christ's Passover, and, for Muslims, the world is the dominion of God, who alone is "the Real" and who voluntarily shares His realness and goodness with creation (Murata 2006, 115). Those who are driven by mistrust easily retreat into the righteous purity of a siege mentality; the truth on which they claim to have a monopoly sets them free from the world but never for its sake. Fanaticism for a particular religious truth naturally coincides with a deep mistrust of all other truths. But what is less obvious is that religious exclusivity ultimately derives from a lack of trust in one's own faith. A narrow-minded particularism that condemns the other religions in toto is nothing but an "argument of force" on the part of those whose faith is, in fact, weak and superficial (Küng 2008, 111). 
When it comes to the fourth way of deviating religiosity, i.e., seeking univocity instead of unity-in-difference, it seems to find a fertile ground in the experience of what Küng terms an ultimately unjustified fundamental trust in reality (Küng 1980, 571).” What is meant by this is a kind of "nameless trust" that either refrains from addressing the transcendentimmanent horizon of human existence as "thou" or addresses it univocally rather than analogically (Tracy 1981, 447). Only "transcendence with a name," conceived in all its uniqueness (Jesus Christ for Christians, Allah for Muslims), insofar as it is accepted trustingly in faith, "equips" the religious believer with a profound sense of identity that opposes a "cheap tolerance." An agnostic-relativistic pluralism that spares itself the trouble of "discerning the spirits" by approving all the religions indiscriminately and exempting them from any criticism, does not call attention to the presence (in all of religions) of untruth, despite all the truth. However liberating and creative of happiness it seems at first, the syncretistic mingling of traditions and creeds that has abandoned all firm standards and norms sooner or later becomes painfully monotonous (Küng 2008, 112).

The common denominator of all these perversions of religion is that each of them in one way or another deems human rationality, and especially the capacity to discern, untrustworthy. Ironically, at the same time, in all the cases God is rendered subject to some sort of reductionist rationalization. Religious fundamentalism, fanaticism and exclusivity all preclude hermeneutic effort aimed at critically discerning the will of God in a given situation. Understood in a rigid and heteronomous manner, sacred texts tend to paralyse the human mind, instead of stimulating it. Established rules and codes of behaviour, which by no means dispense with the need to think of what is good and what is evil, when followed blindly, are likely to lapse into excuses for judging and condemning others and become a means of achieving absolute control over the religious subjects (Kassem 2009, 168). Doctrine, which should serve the purpose of elucidating divine revelation here and now, tends to be reduced to 
a set of propositions formulated in such a way as to end all discussion and maximize certainty. And God becomes nothing more than a licence to realize a particular religious (and often political) agenda. Since everything that potentially transcends the "system" is regarded with deep suspicion and puts quasi-believers on the defensive, God must also fit into their schema or else no longer be considered God.

As for the attempt to "essentialize" different religions, which expresses itself in the univocal, instead of analogical, thinking of religious traditions - it does away with real differences, diffusing them in a "relaxed pluralism of privacies" (Tracy 1981, 451). By uncritically approving and endorsing without differentiation all religions, it leads to what Herbert Marcuse (1969) called a "repressive tolerance," wherein anyone can say anything because no one, finally, is taken seriously. Here, too, God is sacrificed at the altar of a concept (such as Hick's "Ultimate Reality" [1989]), this time a concept that is inclusivist to the point of becoming abstract and unapproachable. To paraphrase the famous Heideggerian expression, before such a nameless God we can neither fall to our knees in awe nor can we play music and dance (see Heidegger 20012, 72).

The key to eliminating the religious perversions in question, i.e., fundamentalism, fanaticism, exclusivity and univocity, lies in paying due attention to, respectively, theological foundation, the certainty of truth, identity, and unity-in-difference.

\section{Rational trust in the essentials: freedom rediscovered}

From the Christian perspective, a "foundation" means first and foremost the all-pervading trust in and faithfulness to that oldest and briefest confession of faith in the New Testament: Iesous Kyrios. Jesus alone is the Christ of God and thus the normative and definitive revelation of God's salvific will in regard to humankind (Küng 2001, 99). A far-reaching consequence of this foundation is that any salvific presence of God throughout all of history 
comes through Jesus Christ. From the Muslim perspective, a "foundation" means first and foremost the all-pervading trust in and obedience to God, as revealed in the Qur'an through Muhammad. Being the Seal of the Prophets, i.e., the last prophet, Muhammad came to deliver God's final word, which, for Muslims, has served as the ultimate norm for all other revelations ever since (Q 33.40).

As suggested by Paul Knitter (2009, 558-560), Muslim theology draws a conclusion from its "prophetology" (the understanding of the finality of Muhammad and the Qur'an) that is the mirror-image of a conclusion that Christianity draws from its Christology (the finality of Jesus and the universal character of the Covenant between God and humanity established through his Passover): the former looks upon outsiders as "anonymous Muslims," while the latter considers them "anonymous Christians." The Qur'an teaches that all human beings are inherently (potentially) "Muslims," for they are all called to submit to Allah (Q 3.52; Murata 2006, 137). The New Testament asserts that no one comes to the Father except through Jesus (John 14.6; Philippians 2.10-11). Like Jesus and the Gospel for Christians, so Muhammad and the Qur'an for Muslims cannot be superseded by anyone or anything else.

However, Firestone (2008, 131-145) points out that, unlike Christianity in relation to Judaism, Islam was prevented by Arabia's seventh-century religious context with its variety of monotheisms (including Judaism and Christianity) from making an exclusive claim of chosenness. Rather, it accepted its elder siblings as "religions of the Book" and, instead of claiming to supersede them, only aimed at "correcting" their errors (82-84). What is more, there is a significant difference between the meanings that Christianity and Islam ascribe to their sense of being elected by God. While Christians understand chosenness in terms of "redemption," Muslims conceive of it in terms of "apocalyptic revelation" (130-146).

In contrast to authors such as Jeremy Cott (1984), ${ }^{7}$ who call for renouncing the religious claims of election altogether, Knitter $(2009,562-566)$ suggests that, on the basis of 
on biblical and qur'anic sources, both Christians and Muslims have a right to identify themselves as chosen by God in a special way. And yet for their sense of chosenness to remain in tune with the biblical and qur'anic understandings of, respectively, God's universal salvific will as disclosed in Jesus the Christ (see, for example, John 1.9; 3.17; Romans 11.32; 1 Timothy 2.4) and Allah's desire for the "supreme success" (al-fawz al- 'azìm) of all the "well-doers" (al-muhsinūn), as revealed in the Qur'an (see, for example, Q 2.112; 4.13; 9.72), both Christians and Muslims ought to be constantly aware that they are chosen not only from all the people of the earth but first and foremost for the sake of the whole of humanity. That is why, if the rootedness in and reliance on theological foundations is not to deteriorate into religious fundamentalism, the sense of chosenness that both Christianity and Islam have inherited from their Jewish mother, cannot be followed by the supersessionist claim according to which God intends Christianity or Islam to supersede all other religions (Knitter 2009, 556-559).

The certainty of truth, built upon trust in the divine Revealer of that truth, frees the believer from suspicion and fear of the religious "other." In addition, for Christians, the nature of the revealed truth - the one God disclosed fully in Jesus Christ - is such that it de facto excludes any claims to "possessing the whole truth." Muslims are also aware of the gap, some sort of discontinuity, between their religious truth, as revealed in the Qur'an, and the fullness of divine truth known only to Allah: "For you is your religion, and for me is my religion" (Q 109.6). Thus, inherent in both Christian and Muslim revelation is the belief that God alone has the whole truth for only God is the absolute truth (Küng 1988, 251). In this sense, Christians and Muslims can be certain of their truth and yet remain protected from religious fanaticism only insofar as they believe ultimately not in Christianity or Islam but in God.

Similarly, the clear sense of one's own identity does not have to lead to exclusivist claims. Can a Christian who affirms what is true and holy in other religions deny that their 
followers achieve salvation not despite but through their faith? (Paul VI 1965a, §2) Does one have to be a Muslim (a member of the umma) in order to be "muslim" with a small ' $m$ ', i.e., 'submitted to God'? (Aydin 2009) Does not consistent trust in God's mercy presuppose the equality of all who trustingly rely on God's mercy?

The Qur'an asserts that, if God had so willed, humankind could have been created as one single community, umma (Q 5.48). Since it was not, one may assume that human diversity - be it cultural or religious - constitutes God's gift and, at the same time, God's task. Christianity, at least in a post-Vatican II era, also acknowledges that the Holy Spirit offers to all people, in a way known only to God, the possibility of being made "partners" in the paschal mystery of Jesus Christ (Paul VI 1965b, 22). Hence, the dynamic development, in recent decades, of a Christian theology of religions that seeks ways to locate the overall plan of salvation among various religious traditions. Fulfilling this task often surpasses human capacities, but what is impossible for humans is not impossible for God (Matthew 19.26). "Wherever you are, Allah will bring you all together. Surely Allah is able to do all things" (Q 2.148). Grounded in that faith, Muslims and Christians may share with other religious believers profound confidence in the human capacity for genuine dialogue.

Finally, seeking unity-in-difference rather than univocity precludes one from succumbing to the temptations of a "lazy pluralism" à la John Hick, which reduces the essentially different theological notions of God to the anaemic concept of the "Ultimate Reality.” Küng $(1980,626)$ rightly points out that the understanding of God on the part of the religions as a whole is definite but not coherent: "it is impossible to believe in all gods at the same time." Thus, both arrogant absolutism, not accepting any other claim, and a weak eclecticism that accepts a little of everything, should be discarded for the sake of an inclusive Christian/Muslim universalism that claims for Christianity/Islam, not exclusiveness, but a certainly uniqueness (Küng 2008, 112). 
Without affirming God, one does not know why one can trust reality - thus we have learned from Küng. Unlike diverse perversions of religion, be it openly oppressive or apparently emancipating but de facto void and futile, a truly liberating religiosity is nourished by an ultimately justified fundamental trust and thus displays a radical rationality, which should never be confused with reductionist rationalization (Küng 1980, 572). That "intrinsic rationality" of human reason, which is in charge in all our doubting and thinking, intuitions and deductions alike, is in a sense guaranteed by God and enables humans to trust in God not against reason, but on the basis of it (574). Like fundamental trust, so, too, trust in God is by no means irrational, but - quite the opposite - it constitutes the superrational ground for all rationality. Religious believers should never render God subject to rationality but, by realizing that God is the ultimate source of human rationality, both Christians and Muslims are invited to such hermeneutics of divine revelation that would allow them to take it for what it really is. Perhaps then, alongside the liberating principles inherent in both traditions and recently brought to the fore by liberation theologies, this profound trust in human rationality - so prominent, for example, in the various Thomistic schools, the great scholarship of the Abbasid Empire and the system of thought developed by al-Ghazāli - is precisely what must be restored to the awareness of Christian and Muslim believers in order for us to resist the all too persistent perversions of our religions.

The above considerations indicate that liberation is correlated not only with a genuine religiosity at large, but also with the very core of Christian and Muslim faith. To complement this study, the notion of freedom stemming from and resulting in fundamental trust will now be investigated theologically, i.e., examined against the background of selected Christian and Muslim insights on faith conceived of as trust. 


\section{Trust as sacramental presence in the world: charis-pistis-caritas}

Traditional Christian ways of thinking about the relation between God and humanity are centred on three steps, often understood chronologically: (1) a free gift of God's grace; (2) human free response of faith; and (3) active love as the ultimate fruit of grace received through faith. Hence the title triad: charis-pistis-caritas. ${ }^{8}$ However, the interrelation between these three "moments" in Christian life can be seen in a much more dynamic way.

When talking about grace or favour, the Old Testament uses the word chen. The biblical authors repeatedly speak of finding "favour" (chen) in the eyes of God or other humans (see, for example, Genesis 6.8; 19.19; 33.15; Exodus 33.12; 34.9; I Samuel 1.18; 27.5; Esther 2.7). Such favour is given freely, not in consideration of any claim or merit, and it always carries with it the bestowal of certain blessings. Thus, far from being an abstract quality, grace appears here as an active, working principle that manifests itself in beneficent acts. Also in Paul, charis does not mean primarily a divine attribute, an attitude or disposition of God. Rather, it denotes a dynamic, holistic and relational act of God's generosity, "the power of salvation which finds expression in specific gifts, acts, and spheres and which is even individualised in the charismata" (Käsemann 1980, 14). Seen through the lens of these etymological-biblical considerations, grace - as effective divine power experienced by the human person - has God's own self as its primary content and caritas as its primary manifestation (Dunn et al. 1988, 17).

Grace understood in the Rahnerian sense, i.e., as God's self-communication through God's Spirit to human existence, is thus a free (trans)personal act between the Triune God and the human person. Insofar as it involves two freedoms - divine and human - it also entails a risk on the part of the self-disclosing God. It is not merely a matter of revealing something about God, a "message" that can be either accepted or dismissed. God's selfdisclosure (apokalypsis) coincides with God's self-emptying (kenosis), whose last word is the 
crucifixion of Jesus. In that enterprise, God puts at stake not something but everything. Does not such a venture require a great trust? We are not accustomed to thinking about God as being trustful toward a human person or humankind in general. However, the dynamics of grace and faith suggests that God's self-communication implies an almost absurd trust in human freedom. Is not the history of divine self-revelation a series of God's failures, with the rejection of the Son by his own people (John 1:11) being the climax and matrix of all human "NOs" to God? And yet from the faith of the few who, filled with the Spirit, said "YES" to this ultimate revelation of God through Jesus, ecclesia was born. As the mystical body of that dead and risen Christ, the Church exists in the midst of the world as a living sign, a sacrament, of human fragile trust in response to God's primordial and unfailing trust.

Furthermore, the reality of love is intertwined with grace and faith in such a way that no clear demarcation line can be drawn between them. As Pope Benedict points out in Caritas in Veritate $(2005,5)$, charity signifies at once love received and love given. It can be equated with grace (charis) in the sense that it stems from the wellspring of the Father's love for the Son, in the Holy Spirit. Love can be also conceived as the natural manifestation and extension of faith (pistis) which in itself (i.e., without works) remains dead (James 2.17) and which, by its very nature, is meant to work through caritas (Galatians 5.6).

In the same vein, Küng $(1988,202)$ notes that being a gift, trust "remains at the same time a continual task, a rationally responsible - hence thoroughly sensible - act of daring." Only by looking at trust in terms of both gift of grace and task of love, we can grasp the subtle yet critical discrepancy between fundamental trust and faith in God. Put briefly, saying "YES" to reality as a whole is a necessary but not sufficient condition of love. Unless the primary ground, deepest support, and ultimate goal of reality, by no means identical with reality itself, is sought and eventually addressed as "thou," fundamental trust is incapable, on 
its own, of evoking caritas. The equation is reversible: Love serves as a litmus test to determine the genuineness of one's religious faith.

To sum up, the theological triad of grace, faith and love can be interpreted through the prism of the liberating power of trust. Fundamental trust that is lived every day just by going on at all is organically connected with religious faith disclosed decisively in God's selfrevealing love, whose ultimate Word is Jesus (Tracy 1981, 430). Both basic trust and religious faith are thereby accounted for by the all-pervasive grace of the constitutive Christevent. God's absolute trust in human freedom, manifested in God's liberating act in Jesus Christ and accepted with unqualified trust by the community of believers, constitutes the very condition of the possibility of Christian manifestation, proclamation and prophetic action the three essential modes of the Church's salvific presence in the world (448). In a sense, trust itself - both in reality and in God - appears as a mysterion, a sacrament, through which God becomes present in the midst of human existence. On the one hand, the experience of grace as giftedness liberates the self to appropriate as one's own the fundamental trust that is the first experience of that gift. When this trust is carried lovingly, it reveals itself as a trust in the radical immanence of God in all reality (432). On the other hand, the gift of trust in reality as a whole illuminates one's faith in God as revealed in the Christ-event. What is more, it frees it to be shared in love with others whose faiths - as different from (and sometimes, indeed, opposed to) one's own faith as they are - not only appear to be rooted in the same fundamental trust but also to bear the same universal fruits of caritas.

Before concluding by looking at liberating trust as a key to interfaith relations, and to Christian-Muslim dialogue in particular, let me venture an attempt at interpreting the correlation between faith and trust from the standpoint of Muslim theology. 


\section{Trust as a foundation of responsible service: $\bar{\imath} m \bar{a} n-i s l \bar{a} m-s a l \bar{a} m$}

According to Islamic teaching, human beings exist to be voluntary servants of God (Q 51.56). Submission (islām) is at the very core of Muslim theory and praxis. That does not mean, however, that the Prophet's testimony is supposed to be accepted against or regardless of the believer's reason. According to Fazlur Rahman, a Muslim is not merely supposed to surrender to a series of commands but must also discover and understand the nature of God's message and command first before s/he can trustfully comply with it (Rahman 1967, 13-14; Kamali 2002, 14). As illustrated by the shahāda, Islamic faith has nothing mysterious about it; it implies consent to two fundamental truths, neither of which transcends human reason: monotheism, which is looked upon as rationally deducible, and Muhammad's prophethood, which is historically verifiable (Küng et al. 1986, 48). What a Muslim expresses by his or her religious practices is always one and the same thing: his or her trustful obedience to God. Thus Islamic faith is neither irrational nor rationally provable; rather - to follow Küng's (2007, 89-90) conceptuality - it is a highly reasonable trust, which includes believing something to be true and a trustful surrender to "the Real." Thus, it is not surprising that the word $\bar{\imath} \bar{a} n$, meaning "faith," is often used in the Qur'an in the same sense as isläm, "submission."

As mentioned above, on the inner-Muslim ground, one cannot deal with any topic whatsoever without reference to the notion of tawhìd. This principle also applies to the topic of trust. Probably no one has examined the organic connection between tawakkul (trust in God) (see, for example, Q 3.159; 5.23; 8.49; 14.12; 65.3) and tawhīd (faith in divine unity) as elaborately as the medieval scholar al-Ghazālī (c. 1058-1111) (see, for example, Ghazālī 2001). On the one hand, trust in divine providence, like everything in Islam, is grounded in tawhìd. On the other, a life of trust constitutes the ultimate test of the human understanding of divine unity (xiv-xvi). Murata (2006, 115-116) maintains that the Islamic way has always 
been rooted in a hermeneutics of trust, a trust directed at God, not at human beings. Suffice it to say that the Qur'an speaks of trust (tawakkul) in 40 verses, and in every case Allah is the object of that trust (see, for example, Q 3.122; 11.56; 12.67; 16.99). Always ready to unmask the ever-present threat of idolatry, Islam stresses that there is absolutely nothing in the world to which a person might completely entrust herself. Only God, to whom humans are accountable directly, ${ }^{9}$ can be the ultimate object of one's trust (Q 9.51; 57.22f.).

Does this simply render "trust in reality as a whole" unacceptable from the Muslim point of view? Since I am not an Islamic theologian or expert, I stand ready to be corrected, but it seems to me that the concept of fundamental trust may fit very well with the Muslim worldview provided the notion of "reality" is theologically qualified. Far from being autonomous in any regard, reality must be consistently interpreted as autonomy founded on theonomy, the rule of God. This view of reality is encapsulated in one of the 99 names of God, the name which, in a sense, brings home the meaning of tawhīd more clearly than any other: al-haqq (the Real). In Murata's words:

God is the Real; there is nothing real but the Real; everything other than God is unreal, ephemeral, transitory, illusory, vanishing, nothing. In short, every quality and characteristic of things that has a positive side to it derives from a divine quality and owes its existence to God.. $(2006,60)$

It is true that a Muslim believer cannot entrust herself or himself to anything but God (Ghazāli 2001, 5-6). However, since God is "the Real" in whose realness the whole of reality ${ }^{10}$ participates, it seems that trust in God, grounded in belief in divine oneness, cannot be ultimately divorced from fundamental trust in reality as a whole insofar as it draws it realness from the Real (Murata 2006, 67-68). 
Therefore, alongside the theological concept of trust in God (tawakkul) that is intrinsic to the ethos of Islam, and various concepts of social trust, fundamental trust may be seen as an implicit aspect of a general Arabic concept of trust, thiqa. ${ }^{11}$ The latter is closely linked to the Muslim central belief in the absolute trustfulness of Allah and thereby indirectly entails the trustfulness of human reality conceived of as God's creation and rule (Eggen 2010).

But there is another notion in the Qur'an that reveals a yet different dimension of trust, namely amāna. According to the qur'anic witness, amāna designates a special responsibility that God offered to the heavens, the earth and the mountains, but they all refused; finally, human beings agreed to carry it (Q 33.72). Here, "Trust" is understood as something precious that one person asks another person to hold for safekeeping. In this case, God has entrusted something to human beings, and they are to hold it for Him; but on the appropriate occasion, they will have to return it (Murata 2008, 134, 336-337). "Trust" in this sense refers to the sum total of specific characteristics that set human beings apart from other creatures. Creatures are all muslim and 'abd in the most general sense of the terms, so they have no choice but to give back to God what they were holding for safekeeping. In this regard, human beings are no different from the rest of creation. Speaking of amāna, the Qur'an does not refer, then, to universal "compulsory trust." Rather, it points to some sort of free choice, something that pertains exclusively to human beings, as only they, having carried the Trust, are called to choose freely to be God's servants in order to live up to their potential. Only from humans does the Qur'an demand a voluntary isläm over and above universal and compulsory islām $(113,134,184)$.

This "Trust" is identified by most Islamic scholars with the vicegerency given to humans by God. Human beings are set in creation with responsibility for the world, a responsibility that they share with God. The Qur'an describes as "wrongdoers" those who, 
instead of treating the divine attributes that they have received from God as a Trust, act as if the attributes belong to them and can be used in any way they see fit (Q 33.72). Thus, it is not enough simply to be human to carry the Trust; such a vicegerency must be always preceded by servanthood, as one cannot represent Allah until one follows divine commands (Murata 2008, 125). What is more, carrying the Trust (amāna) involves personal freedom and thus also personal trust in God (tawakkul). "The paradoxical anthropological key statement of the Qur'an is grounded in the fact that as the servant of God, the human being is at the same time God's khalifa, his 'successor,' 'representative on earth"”' (Küng 2007, 83; Q 2.30). Vicegerency given by God entails human responsibility for the world in its diverse aspects: political, social, religious, ecological, and so on. As a religion of the law, Islam does not merely orient men and women to the next life; it also reaches a shaping hand into the here and now by having an all-encompassing impact on the life of the believers. Often unmarked by the Western separation between the secular and the spiritual, Muslims feel truly responsible to God for the way they run the world around them (Küng et al. 1986, 40; Omar 2008, 97).

A radical example of such a sense of responsibility - and at the same time an insightful theoretical framework for a Christian-Muslim study on liberation and religiosity, as set out in this article - can be found in Farid Esack's Islamic perspective on interreligious solidarity against oppression. Esack provides an insider's view of the South African struggle for liberation, in which progressive Islam confronted not only those in power but also Muslim conservatives led by clerics whose stance on non-involvement in politics was, de facto, support for the apartheid status quo. He finds the hermeneutic key to a qur'anic theology of liberation in interpreting the key suras in their own historical context and then making them relevant to a particular kairos and social-political context (Esack 1997, 82-86). His creative insights concerning root qur'anic concepts include: (1) that the separation of faith (immann) 
from righteous action is totally untenable and absurd; (2) that "islam" embraces all who submit to the will of God; (3) that the fact of religious diversity is the will of God; and (4) that inclusivity of calling all to God and God's way is geared to specific objectives to free humankind from injustice (Thomas 1997, 87).

Peacemaking is another central aspect of the divine stewardship. Fethullah Gülen's teachings about hizmet, i.e., altruistic service for the common good, which have attracted a large number of supporters around the world, put great emphasis on peace. According to hizmet, Muslim trust in Allah's justice and mercifulness, especially when seen through the prism of the human person's privileged position as God's khalīfa (representative on earth), should find its fulfilment in individual and social efforts aimed at building world peace and justice (Gülen 2004). The etymological connection between the two Arabic notions, islām (submission) and salām (peace), is not coincidental. Muslims believe that true peace can only be achieved through unconditional obedience to God's will. Therefore, peace (like everything in Islam) ultimately depends on trustful submission to God (Engineer 2005). Peacemaking, as a crucial aspect of human development, is seen as a Godly act worthy of praise and reward, whereas breaching peace is a sinful activity that corrupts the divinely intended order (Al-Naim 1990).

The proper function of religion, including Islam, consists in "binding people with the Absolute" so that they are bound to be ultimately free. What connects the approaches of Esack, Gülen, Ali Shari’ati (1980; 1981), Asghar ‘Ali Engineer (1988; 1990), Irfan Omar (2008) and other representatives of so-called "Islamic revivalism" or "Muslim liberation theology" is the underlying conviction that, even though religion cannot be reduced to its social-political dimension, it will be not capable of performing its proper function unless it becomes a vehicle of political, social and economic liberation here and now (Yadegari 1986, 38). 


\section{Christians and Muslims today: towards dialogue, trustingly}

Küng $(1988,227)$ insists that, in our day, any theology of either Christian or Muslim provenance that aspires to an ecumenical dimension has to clearly acknowledge its share of responsibility for world peace. As believers, and especially as theologians, we must urgently work out what holds the great world religions together in spite of everything that seems to divide them. Referring to the universal (trans-religious) principle of responsibility, Küng $(2001,55)$ asks, "What can religions contribute to the furthering of an ethic, despite their very different systems of dogmas and symbols that distinguishes them from philosophy, political pragmatism, international organisations, and philanthropic concerns of all kinds?"

All these challenges can only be dealt with by a common effort on the part of all religious believers, regardless of their confessional affiliation. Certain authors suggest that nowadays we are witnessing "a dramatically new shift in the history of humankind from proclamation to dialogue" (Smith 2000, 493). While it must be admitted that the reality of self-exposure to the other is a condition for the possibility of authentic conversation, we should, as religious people, foster an interfaith dialogue that is rooted in the particular geniuses of our respective traditions, frankly proclaimed to the world (Tracy 1981, 446-448). True freedom, as understood by all the great religions, is always a freedom for the truth. Only by remaining faithful to our own religious identity, can we analogically reach out to the hard concreteness of other religious believers to eventually find that we arrive where we began "only to know the place for the first time" (Eliot 1942, IV.5.28-29).

For a Christian-Muslim encounter to be fruitful, what Knitter $(2009,556-562)$ terms "sibling rivalry" contained in mutual supersessionist claims, must be overcome so that "siblings opportunities" can be fully engaged. In this light, the shared notion of monotheism, rather than that of chosenness, which - as we have seen - often entails supersessionist claims, holds greater dialogical potential. While the former avers that God is unique, the latter makes 
the believers unique (Peters 2003, 64). In the same vein, Firestone $(2008,150)$ calls for Christian and Muslim claims of chosenness to be lived in a tolerant and inclusive way: "If God created everyone to be absolutely unique, are we not all chosen?" Certainly our two traditions are endowed with rich liberating resources and capable of collaborating in endeavours aimed at protecting and furthering humanity and humanness against all oppression, on the basis of general ethical criteria. By doing so, Christianity and Islam can also foster a universal religious commitment to the engagement of all religious believers in activating the liberating and uniting potential of their respective faiths.

When it comes to specifically Christian or specifically Muslim criteria, they can only be applied directly to Christianity or Islam, in self-criticism. However, Christian criteria can also be applied indirectly to Islam, and vice versa. The leading question here is whether and to what degree is something of that spirit of Jesus Christ manifested in Islam, too, both in theory and in praxis, and, reciprocally, whether and to what degree something of that voluntary and liberating submission to God which we describe as Muslim can also be found in Christianity. When free from the tiniest traces of arrogance, such hermeneutic empathy may transpose interfaith dialogue into a new, deeper dimension, where the prophetic message of each tradition is no longer as a source of rivalry and conflict but rather a tool in holy “competing in righteousness" (Q 5.48). The significance of such a dialogue goes far beyond the province of mere scholarship. Provided it is grounded in friendship between its participants, Muslims and Christians will be able to appreciate the density and compactness of their respective faiths and their trust in God (Zebiri 1997, 224), stemming from and resulting in their fundamental trust in reality as a whole. 


\section{Conclusion}

This article has argued that the same liberating trust that allows the birth of a genuine religiosity implies a responsibility for making one's faith the source of freedom, never of oppression. Both the gift, i.e., freedom from suspicion and mistrust, and the task, i.e., trustful commitment to liberating human realities, are shared by all religious people: what comes to us as a gift must be turned into our common task and effort, since the two interpenetrate one another in an indissoluble way (Küng 1980, 452).

The theological interpretations of Christian and Muslim faith proposed above may at times appear to be heavily theoretical, not to say abstract. However, the intention was to show that, by using the conceptual framework provided mainly by Küng, one can employ the notion of fundamental trust as a hermeneutical key in the ecumenically oriented theology of religions. Unlike the notion of liberation, which is drawn on abundantly in current religious and theological reflection, that of trust is still to receive due attention. By looking at these two concepts as mutually correlated, I have aimed at establishing a new layer for interpreting religious phenomena. A more historically and culturally grounded reflection on how religious believers internalize and externalize fundamental (mis)trust in regard to reality must follow. Furthermore, once more I acknowledge my evident limitations regarding Islamic theology. As a Catholic theologian, I stand ready to be corrected in my attempts to groove with Islamic thought. This study is an open invitation to my Muslim fellow-theologians to engage with Küng's notion of fundamental trust and my interpretation of it with regard to mutual correlation between religiosity and liberation.

If Christianity and Islam are expected to continue to "operate in our common secular lives as an authentic disclosure which both bespeaks certain inevitable limits-to our lives and manifests some final reality which functions as a trustworthy limit-of life itself' (Tracy 1975, 109), the question of fundamental trust must be addressed both theologically and 
ecumenically. In the face of the crisis of global trust that is evident in the international political and social arenas (Soderberg 2006), world religions may either contribute to the growing climate of mistrust or challenge it. A trustful attitude toward the world and humanity - seen also as an alternative to (or even a sign of protest against) the Western hermeneutics of suspicion - should become a distinguishing mark of all Christians and Muslims eager to pursue global ecumenism, which the present suggests and the future demands. Liberating resources inherent in our traditions cannot be exploited unless we become fully aware of the mutual correlation between our faith in God and our fundamental trust in reality as a whole, which entails confidence in human rationality and religious believers' capacity for dialogue seeking unity-in-difference.

\title{
Notes
}

\begin{abstract}
${ }^{1}$ A number of empirical studies have explored the interplay between religion and various forms of trust - individual, institutional, social, etc. (e.g., Addai, Opoku-Agyeman and Ghartey 2013; Johansson-Stenman, Mahmud and Martinsson 2009). However, one must clearly distinguish such empirically verifiable forms of trust from fundamental trust in reality, as explicated by Küng. The last cannot, in itself, be measured; nonetheless, on the basis of the cultural, social and political dimensions of a given form of religiosity, one may attempt to deduce the underlying fundamental trust or lack of it.
\end{abstract}

${ }^{2}$ In this context, one may repeat the call expressed by Küng at a UNESCO conference held in Paris in 1991: "Our religions must put a stop to these perversions of Religion!" (Küng 1991, 24).

${ }^{3}$ The analogy between the position of Jesus Christ in Christianity and the Qur'an in Islam is not coincidental. While one may imagine a Christianity without the New Testament, sustained merely by an oral tradition, one cannot imagine a Christianity without Christ. For Muslims, the Qur'an is God's Word, whereas Muhammad is simply the messenger; here the message, and not the messenger, constitutes the primary issue. That is why one can imagine Islam without Muhammad, but not without the Qur'an (Murata 2006, 173).

${ }^{4}$ That is what distinguishes it from the modern concept of freedom and, in a sense, also from the Christian understanding of human freedom, with its strong emphasis on the anthropology of the imago Dei. In this context, one can understand the source of the multi-faceted incompatibilities of Shari a with modern, Western-derived conceptions of universal human rights based on the purely "horizontal" concept of human freedom (Bostom 2012). 
5 The creative interpretations of Maurice de la Taille (on "actuation"), Karl Rahner (on "quasi-formal causality"), and Bernard Lonergan (on "contingent predication") appear to be the most fruitful contemporary interpretations of Aquinas on this controversial issue (Tracy 1991, 111).

${ }^{6}$ Firestone $(2008,129-130)$ points to a surprising reversal of the modern (especially postVatican II) Christian trend toward inclusion, which coincides with a certain movement among some radical politicized Muslims toward religious totalitarianism. Both these trends constitute a radical change in relation to the traditions that have prevailed in each religion throughout centuries.

${ }^{7}$ Pointing to the connection between the concept of election ("the security of the insecure") and the brutality of conquest, Cott $(1984,199 ; 225-226)$ argues that the singularity inherent in the very idea of election, with its factionalizing tendency, is contradicted by the fact of religious pluralism and must be thereby re-appropriated theologically by means of embracing anti-election biblical traditions, such as the theology of the stranger, which naturally transcends narrow nationalism.

${ }^{8}$ My use of the Latin term caritas, instead of the Greek agape, is intentional. Following Augustine, I understand caritas as a broader reality that incorporates not only agape but also eros which, when disciplined and purified, may provide "a certain foretaste of the pinnacle of our existence, of that beatitude for which our whole being yearns" (Benedict XVI 2005, §4).

${ }^{9}$ Küng $(2007,153)$ reminds us that original Islam does not know mediators, whether priests or saints. Even the Prophet himself cannot be considered a mediator.

${ }^{10}$ One must be careful not to reduce the notion of reality to the physical universe or cosmos, as those are commonly defined by the Qur'an as "everything other than God" and thereby "unreal" (Murata 2006, 60).

${ }^{11}$ To appreciate how deeply the idea of trust is rooted in the Muslim mentality, suffice it to mention a very telling decision made long ago by Sunnis and Shi'ites alike with regard to the interpretation of Islamic tradition (sunna). With the trust characteristic of tradespeople in a society where everything was out in the open, and in the absence of any universal religious magisterium, the Arab Muslims used to recognize the truth of a particular dictum not by its contents, inner logic or agreement with the "system," but by the credibility of the person who was its source. Such "truth by handshake" - to use Josef van Ess's expression (Küng et al. 1986, 42) - was not derived discursively or preached rhetorically, but simply granted as an "advance" by the trusted bearers of tradition (42). 


\section{References}

Addai, I., C. Opoku-Agyeman, and H. T. Ghartey. 2013. "An Exploratory Study of Religion and Trust in Ghana.” Social Indicators Research 110 (3): 993-1012.

Alexander, S. 2013. “'Which Religion Will Win?’ An End to Triumphalism in MuslimChristian Relations." Talk given at the University of St Thomas, Minnesota. Excerpts available at www.stthomas.edu/news/2013/10/22/catholic-muslim-religious-triumphalism (accessed March 21, 2014).

Al-Naim, A. A. 1990. Toward an Islamic Reformation: Civil Liberties, Human Rights, and International Law. Syracuse, NY: Syracuse University Press.

Al-Șadr, B. 2009. "Freedom According to Islam and Capitalism.” English Islam Times. Accessed March 21, 2014. http://islamtimes.org/vdcd290k6yt05.mey.html

Aydin, M. 2000. "Is There Only One Way to God? A Muslim View." Studies in Interreligious Dialogue, 10(2), 148-159.

Benedict XVI. 2005. Deus caritas est (Encyclical Letter). Accessed June 20, 2014. http://www.vatican.va/holy_father/benedict_xvi/encyclicals/documents/hf_benxvi_enc_20051225_deus-caritas-est_en.html

Bostom, Andrew G. 2012. Sharia versus Freedom: The Legacy of Islamic Totalitarianism. Amherst, NY: Prometheus Books.

Buber, M. 1937. I and Thou. Translated by R. G. Smith. Edinburgh: T.\&T. Clark.

Cott, J. 1984. “The Biblical Problem of Election.” Journal of Ecumenical Studies 21 (2), 199226.

Dunn, J. D. G., G. W. Barker, D. A. Hubbard, and B. M. Metzger. 1988. Romans 1-8. Dallas, TX: Word Books.

Eggen, N. S. 2010. "Trust in Islam and Its Effects on Society." Review of Al-Amāna fì alislām wa-atharuhā fì al-mujtama', by 'Abd al-Lațîf al-Husayn. Islam and Civilisational Renewal 2 (1) (October): 198-201.

Eliot, T. S. 1942. Little Gidding. London: Faber and Faber.

Engineer, A. A. 1988. Religion and Liberation. Delhi: Ajanta Publications.

Engineer, A. A. 1990. Islam and Liberation Theology: Essays on Liberative Elements in Islam. New Delhi: Sterling Publishers. 
Engineer, A. A. (ed.). 2005. On Developing Theology of Peace in Islam. New Delhi: Sterling.

Erikson, E. H. 1980. Identity and the Life Cycle. New York: Norton.

Esack, F. 1997. Qur'an, Liberation and Pluralism: An Islamic Perspective of Interreligious Solidarity against Oppression. Oxford: Oneworld.

Firestone, R. 2008. Who Are the Real Chosen People?: The Meaning of Chosenness in Judaism, Christianity, and Islam. Woodstock, VT: SkyLight Paths.

Ghazālī, A. H. al-. 2001. Faith in Divine Unity and Trust in Divine Providence. Translated by D. B. Burrell. Louisville, KY: Fons Vitae.

Gülen, F. 2004. Toward a Global Civilization of Love and Tolerance. Somerset, NJ: Light, Inc.

Hammarskjöld, D. 1964. Markings. New York: Knopf / London: Faber.

Heidegger, M. 2002. Identity and Difference: The Onto-Theo-Logical Constitution of Metaphysics. Translated by J. Stambaugh. Chicago, IL: University of Chicago Press.

Hick, J. 1989. An Interpretation of Religion: Human Responses to the Transcendent. New Haven, CT: Yale University Press.

Jaspers, K. 1967. Philosophical Faith and Revelation. New York: Harper \& Row.

Johansson-Stenman, O., M. Mahmud, and P. Martinsson. 2009. "Trust and Religion: Experimental Evidence from Rural Bangladesh.” Economica 76 (303): 462-485.

Kamali, M. H. 2002. Freedom, Equality, and Justice in Islam. Cambridge: Islamic Texts Society.

Käsemann, E. 1980. Commentary on Romans. Translated by G. Bromiley. Grand Rapids, MI: Eerdmans.

Kassem, A. S. 2009. "The Concept of Freedom in the Quran." American International Journal of Contemporary Research 2 (4): 165-173.

Knitter, P. 2009. "Islam and Christianity: Sibling Rivalries and Sibling Possibilities." Cross Currents 59 (4): 554-575.

Küng, H. 1980. Does God Exist?: An Answer for Today. Translated by E. Quinn. New York: Doubleday. 
Küng, H. 1988. Theology for the Third Millennium: An Ecumenical View. Translated by P. Heinegg. New York: Doubleday.

Küng, H. 1991. "Take Steps Now toward Articulating Global Ethos.” National Catholic Reporter 22 (28, November): 24.

Küng, H. 1996. "Global Ethics and Education.” In The Future of Theology: Essays in Honor of Jürgen Moltmann, edited by M. Volf, C. Krieg, T. Kucharz, et al., 267-283. Grand Rapids, MI: Eerdmans.

Küng, H. 2001. Global Responsibility: In Search of a New World Ethic. New York: Continuum.

Küng, H. 2007. Islam: Past, Present and Future. Translated by J. Bowden. Oxford: Oneworld.

Küng, H. 2008. On Being a Christian. Translated by E. Quinn, London/New York: Continuum.

Küng, H., J. van Ess, H. von Stietencron, and H. Bechert. 1986. Christianity and World Religions: Paths of Dialogue with Islam, Hinduism, and Buddhism. Translated by P. Heinegg, New York: Doubleday.

Luther, M. 1959. The Book of Concord: The Confessions of the Evangelical Lutheran Church, edited and translated by T. G. Tappert. Philadelphia, PA: Fortress Press.

Marcuse, H. 1969. "Repressive Tolerance." In A Critique of Pure Tolerance, edited by R. P. Wolff, B. Moore Jr, and H. Marcuse, 95-137. Boston, MA: Beacon Press.

Murata, S. 2006. The Vision of Islam. London: I. B. Tauris.

Omar, I. A. 2008. "Islam.” In The Hope of Liberation in World Religion, edited by M. A. de la Torre, 91-112. Waco, TX: Baylor University Press.

Paul VI. 1965a. Nostra Aetate: Declaration on the Relation of the Church to Non-Christian Religions. Accessed on June 20, 2014. http://www.vatican.va/archive/hist_councils/ii_vatican_council/documents/vatii_decl_19651028_nostra-aetate_en.html

Paul VI. 1965b. Gaudium et Spes: Dogmatic Constitution on the Church in the Modern World. Accessed on June 20, 2014. http://www.vatican.va/archive/hist_councils/ii_vatican_council/documents/vatii_cons_19651207_gaudium-et-spes_en.html 
Peters, F. E. 2003. The Monotheists: Jews, Christians, and Muslims in Conflict and Competition. Princeton, NJ: Princeton University Press.

Rahman, F. 1967. "The Qur'anic Concept of God, the Universe and Man.” Islamic Studies 6(1): 1-19.

Shari'ati, A. 1980. Marxism and Other Western Fallacies: An Islamic Critique. Translated by R. Campbell. Berkeley, CA: Mizan Press.

Shari'ati, A. 1981. Man and Islam. Translated by F. Marjani. Houston, TX: Free Islamic Literature.

Smith, J. I. 2000. "Islam and Christianity." Review of Mutual Perceptions since the mid-20th Century, edited by J. Waardenburg. The Muslim World 90 (3/4): 492-493.

Soderberg, N. E. 2006. "The Crisis of Global Trust and the Failure of the 2005 World Summit." Ethics and International Affairs 20 (2): 235-240.

Thomas, N. E. 1997. Review of Qur'an, Liberation and Pluralism: An Islamic Perspective of Interreligious Solidarity against Oppression, by F. Esack. Journal of Ecumenical Studies 34: 86-87.

Tillich, P. 1951. Systematic Theology. Vol. 1: Reason and Revelation: Being and God. Chicago, IL: University of Chicago Press.

Tracy, D. 1975. Blessed Rage for Order: The New Pluralism in Theology. New York: Seabury Press.

Tracy, D. 1981. The Analogical Imagination: Christian Theology and the Culture of Pluralism. Louvain: Peeters Press / Grand Rapids, MI: Eerdmans.

Tracy, D. 1991. Dialogue with the Other: The Inter-religious Dialogue. Louvain: Peeters Press / Grand Rapids, MI: Eerdmans.

von Sinner, R. 2005. "Trust and Convivência: Contributions to a Hermeneutics of Trust in Communal." The Ecumenical Review 57 (3): 322-341.

Yadegari, M. 1986. "Liberation Theology and Islamic Revivalism.” Journal of Religious Thought 43 (2): 38-50.

Zebiri, K. 1997. Muslims and Christians Face to Face. Rockport, MA: Oneworld. 